\title{
CFTR-deficiency renders mice highly susceptible to cutaneous symptoms during mite infestation
}

\author{
Yasuaki Hashimoto ${ }^{1, *}$, Tsuyoshi Shuto $^{1, *}$, Shota Mizunoe ${ }^{1, *}$, Azusa Tomita ${ }^{1}$, Tomoaki Koga ${ }^{1}$, Takashi Sato ${ }^{1}$, \\ Motohiro Takeya ${ }^{2}$, Mary Ann Suico ${ }^{1}$, Akiko Niibori ${ }^{1}$, Takuya Sugahara ${ }^{1}$, Shogo Shimasaki ${ }^{1}$, Takashi Sugiyama ${ }^{1}$, \\ Bob Scholte ${ }^{3}$ and Hirofumi Kai ${ }^{1}$
}

Pruritus, also known as itch, is a sensation that causes a desire to scratch. Prolonged scratching exacerbates skin lesions in several skin diseases such as atopic dermatitis. Here, we identify the cystic fibrosis transmembrane conductance regulator (CFTR/Cftr), an integral membrane protein that mediates transepithelial chloride transport, as a determinant factor in mice for the susceptibility to several cutaneous symptoms during mite infestation. Mice that endogenously express

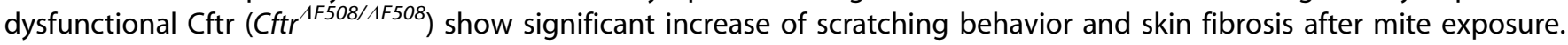
These phenotypes were due to the increased expression of nerve growth factor (NGF) that augments the sensitization of peripheral nerve fibers. Moreover, protein gene product 9.5 (PGP9.5)-positive neurites were abundant in the epidermis of mite-infested $\mathrm{Cftr}^{4 F 508 / \Delta F 508}$ mice. Furthermore, mite-infested $\mathrm{Cftr}^{+/+}$mice orally administered with a chloride channel inhibitor glibenclamide had higher scratching count and increased level of NGF than vehicle-treated mice. Consistently, mite extract-exposed primary and transformed human keratinocytes, treated with CFTR inhibitor, had significantly higher level of NGF mRNA compared with vehicle-treated, mite extract-exposed cells. These results reveal that CFTR in keratinocytes plays a critical role for the regulation of peripheral nerve function and pruritus sensation,

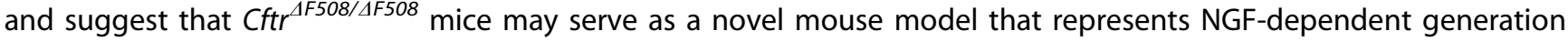
of pruritus.

Laboratory Investigation (2011) 91, 509-518; doi:10.1038/labinvest.2010.193; published online 6 December 2010

KEYWORDS: CFTR; keratinocyte; mite; nerve growth factor; pruritus; scratching behavior

Among cutaneous symptoms, pruritus, also known as itch, is a sensation that causes a desire to scratch. Although itchinduced scratching serves as a physiological self-protective mechanism to prevent the body from being hurt by harmful external agents, prolonged scratching exacerbates skin lesions in several skin diseases such as atopic dermatitis (AD). ${ }^{1,2}$ As reducing itching and scratching is one of the most effective strategies to prevent the aggravation of skin lesions, ${ }^{3}$ identification of the regulatory system to control the itching and scratching is needed to improve quality of life for patients. Recent studies have shown that peripheral and central neural sensitization of nerve fibers plays a role in the pathophysiology of itch. ${ }^{4,5}$ Of these, peripheral mediators that could control the sensitization of nerve fibers have gained importance as an inducer for the progression of several skin diseases. ${ }^{6}$ It has been demonstrated that nerve growth factor (NGF) plays roles in the pathogenesis of itch and itch-induced skin lesions using skin-lesioned $\mathrm{NC} / \mathrm{Nga}$ mice, an animal model for human $\mathrm{AD}$, and that inhibiting the physiological effects and production of NGF prevents these symptoms. ${ }^{7,8}$ Furthermore, AD patients with itch showed significant gains in NGF plasma levels compared to controls, and a correlation was noted between plasma NGF and severity of symptoms. ${ }^{9}$ Thus, NGF plays a role in the regulation of susceptibility to itch reaction and skin lesions.

The cystic fibrosis (CF) transmembrane conductance regulator (CFTR/Cftr), in which a mutation causes the most common lethal inherited disorder $\mathrm{CF},{ }^{10}$ is a polytopic integral

\footnotetext{
'Department of Molecular Medicine, Graduate School of Pharmaceutical Sciences, Global COE 'Cell Fate Regulation Research and Education Unit', Kumamoto University, Kumamoto, Japan; ${ }^{2}$ Department of Cell Pathology, Graduate School of Medical Sciences, Kumamoto University, Kumamoto, Japan and ${ }^{3}$ Department of Cell Biology, Erasmus Medical Centre, Erasmus University, Rotterdam, The Netherlands

Correspondence: Dr T Shuto or Dr H Kai, Department of Molecular Medicine, Graduate School of Pharmaceutical Science, Kumamoto University, 5-1 Oe-Honmachi, Kumamoto 862-0973, Japan.

*These authors contributed equally to this work.
} 
membrane protein that mediates transepithelial chloride transport across epithelial cells in airways, pancreas, intestines, sweat glands and other tissues. ${ }^{11,12}$ CFTR is recognized as a molecule for the control of cellular and tissue homeostasis as CFTR dysfunction in several CFTR-expressing tissues could cause abnormalities such as salty tasting skin, excess mucus production, frequent chest infections and coughing/shortness of breath. ${ }^{10}$ The cause of these abnormalities is not only due to the aberrant regulation of ion transport but of other molecules such as epithelial sodium channel $(\mathrm{ENaC}){ }^{13}$ and aquaporin $3(\mathrm{AQP} 3),{ }^{14}$ which are also known to influence cellular homeostasis. Notably, dysfunction of CFTR/Cftr has also been shown to exaggerate inflammatory responses of cells by increasing the gene expression of several proinflammatory molecules including interleukin (IL)-1 $\beta,{ }^{15} \mathrm{IL}-8,{ }^{15} \mathrm{IL}-17^{16}$ and toll-like receptor-2 $(\mathrm{TLR} 2)^{17}$ in pulmonary tissue. These reports suggest a role of CFTR as a suppressor for inflammation. ${ }^{18}$

Recent report shows that CFTR is also expressed in human epidermis. ${ }^{19}$ It may be therefore possible that CFTR is a regulator of peripheral molecules including NGF in epidermal tissue. To test this possibility, we assessed the effect of CFTR/Cftr dysfunction on the development of cutaneous symptoms (itch, skin fibrosis) using dysfunctional $\mathrm{Cftr}$ $\left(\Delta\right.$ F508-Cftr)-expressing mice $\left(C f t r^{4 F 508 / 4 F 508}\right) .^{20,21}$

\section{MATERIALS AND METHODS}

\section{Animals}

Cftr ${ }^{\text {tmleur }}$ mice, backcrossed to the C57BL/6J genetic background for 13 generations were obtained from the Erasmus MC animal Facility. Male mice (13-16 weeks old; $+/+$, $+/ \Delta \mathrm{F} 508, \Delta \mathrm{F} 508 / \Delta \mathrm{F} 508)$ were bred and genotyped according to the protocol previously described. ${ }^{20,21} \mathrm{NC} / \mathrm{Nga}$ mice (13-16 weeks old) were obtained from Charles River, Japan. The mice used in this study were housed in a vivarium in accordance with the guidelines of the animal facility center of Kumamoto University. The animals were fed with normal chow ad libitum. All experiments were performed according to the protocols approved by the Animal Welfare Committee of Kumamoto University.

\section{Allergen (Rodent Mite, Myobia musculi) Exposure by Co-habitating with NC/Nga Mice}

CFTR $(+/+,+/ \Delta \mathrm{F} 508, \Delta \mathrm{F} 508 / \Delta \mathrm{F} 508)$ mice and nonlesioned NC/Nga mice (13-16 weeks old, $n=4$ per group) were housed with mite-infested NC/Nga mice (25-30 weeks old with chronic severe dermatitis) for 8 weeks as previously described. ${ }^{22,23}$ We checked the presence of mites on the rostral back in all the mice at 8 weeks after mite exposure and found that no difference was observed among mice.

\section{Glibenclamide Treatment}

Glibenclamide (GLB; Sigma) was dissolved in 1\% Tween 80 (Sigma) solution. Test animals were given $10 \mathrm{mg}$ of GLB per kilogram of body weight, orally administered daily for
6 weeks. The control mice were given an equal volume of the vehicle control. The scratching behavior of GLB-treated mice was measured once a week for $30 \mathrm{~min}$ after GLB administration. After 6 weeks of treatment, mice were killed and tissues were fixed with $10 \%$ formalin solution for immunohistochemistry.

\section{Measurement of Scratching Behavior}

The mice were acclimatized for $30 \mathrm{~min}$ in an observation chamber (length $28 \mathrm{~cm}$, width $15 \mathrm{~cm}$, height $12 \mathrm{~cm}$ ), and the number of scratching movements of hind paws directed at the rostral back was measured for $30 \mathrm{~min}$ as an index for the itch sensation.

\section{Histological Assessment}

Mouse skin tissues were fixed in $10 \%$ formalin at $4^{\circ} \mathrm{C}$ for $24 \mathrm{~h}$, embedded in paraffin block, and cut into $3 \mu \mathrm{m}$ thick sections. Sections were routinely stained with hematoxylin and eosin (H\&E) for light microscopy. In this study, increased epidermalthickened region is measured and the percentage of epidermalthickened region in the back skin of mice was calculated and expressed as: relative percent of epidermal-thickened region $=$ (total length of epidermal-thickened region in the sample $(\mathrm{mm})) /($ total length of skin sample $(\mathrm{mm})) \times 100$.

\section{Immunohistochemical Staining}

Sections were deparaffinized, blocked and stained with rabbit polyclonal anti-human PGP9.5 (RA95101; UltraClone Limited, UK). PGP9.5 is a marker for sensory nerve endings. For NGF staining, the sections after blocking were incubated with rabbit polyclonal anti-mouse NGF antibody (AN-240; Alomone Labs, Israel). The peroxidase activity was visualized with 3,3'-diaminobenzidine, and these sections were treated with hematoxylin for nuclear staining and were mounted with resin. The sections were observed using a microscope (BX50, OLYMPUS). For each section, the area of immunoreactive nerve fibers in the epidermis $\left(\mu \mathrm{m}^{2}\right)$ per skin length $(\mu \mathrm{m})$ was randomly quantified in six fields per mouse by imaging software (WinROOF).

\section{K252a, NGF High-Affinity Receptor TrkA Inhibitor, Treatment}

K252a ( $2 \mu \mathrm{M}$; Calbiochem) was dissolved in dimethyl sulfoxide (DMSO; Wako). Concentrations of these compounds were set at 10 times the dose necessary to inhibit neurite generation initiated by NGF in vitro. ${ }^{24}$ One hundred microliters of K252a was applied to the rostral part of the back of mice five times a week. The scratching behavior of $\mathrm{CFTR}^{4 F 508 / \triangle F 508}$ mice was measured once a week for $30 \mathrm{~min}$ after application of K252a.

\section{Measurement of Transepidermal Water Loss and Serum Levels of Total IgE}

Transepidermal water loss (TEWL) was measured quantitatively using the Tewameter ${ }^{\circledR}$ (TM210, Courage and Khazaka, 
Germany) on the rostral back with shaved skin. The environmental conditions were the same as the breeding conditions. For determination of immunoglobulin E ( IgE), blood was collected from the tail vein, and centrifuged at $2000 \mathrm{~g}$ for $20 \mathrm{~min}$. Serum IgE level was determined with a commercial enzyme-linked immunosorbent assay kit (Yamasa, Chiba, Japan).

\section{Cell Culture and Treatment}

HaCaT cells (CLS Cell Lines Service, Eppelheim, Germany) ${ }^{25}$ were grown and maintained in Dulbecco's modified Eagle's high glucose medium (Wako) supplemented with $10 \%$ fetal bovine serum, $100 \mu \mathrm{g} / \mathrm{ml}$ of penicillin and $100 \mathrm{U} / \mathrm{ml}$ of streptomycin. Normal human epidermal keratinocyte (NHEK) were purchased from Takara Bio (Japan) and were grown and maintained in KGM-2 (Takara Bio, Japan) according to the recommended protocol. Cells were treated with DMSO or CFTR-inh172 (10 $\mu \mathrm{M}$; Calbiochem) for $12 \mathrm{~h}$ before the assays. Cells were incubated with mite extract $(50 \mu \mathrm{g} / \mathrm{ml}$; Dermatophagoides farinae crude extract, LSL, Tokyo, Japan) for $4 \mathrm{~h}$ before harvesting the cells for real-time quantitative RT-PCR assay.

\section{Western Blotting}

Lysates from HaCaT, 16HBE14o-, Calu-3 and WT-CFTRexpressing $\mathrm{CHO}$ cells were prepared and $45 \mu \mathrm{g}$ of protein was loaded in each well. Analysis was done by SDS-PAGE and western blotting using rabbit polyclonal anti-CFTR antibody (\#2269, Cell Signaling Technology, Danvers, MA, USA) and rabbit polyclonal anti-calnexin (C-terminus specific) (SPA860; Stressgen Bioreagents, Ann Arbor, MI, USA) as described previously. ${ }^{26}$

\section{Immunocytochemical Analysis}

Immunocytochemical analysis was performed as described previously. ${ }^{26}$ Cells were stained with propidium iodide (PI) $(1 \mu \mathrm{g} / \mathrm{ml} \mathrm{PI}, 10 \mu \mathrm{g} / \mathrm{ml}$ RNase in PBS) for $30 \mathrm{~min}$ and then stained with anti-CFTR antibody (C-terminus specific; Genzyme Techne, Cambridge, MA, USA) and Alexa Flour 546 conjugated secondary antibody (Molecular Probes, Eugene, OR, USA).

\footnotetext{
125I Efflux Assay

${ }^{125}$ I efflux experiments using HaCaT or 16HBE14o- cells were performed as described previously. ${ }^{27}$ Briefly, cells were grown on fibronectin-coated (for 16HBE14o-) or non-coated (for $\mathrm{HaCaT}$ ) six-well plates. Confluent cells were rinsed two times with $1 \mathrm{ml}$ of efflux buffer $\left(140 \mathrm{mM} \mathrm{NaCl}, 3.3 \mathrm{mM} \mathrm{KH}_{2} \mathrm{PO}_{4}\right.$, $0.83 \mathrm{mM} \mathrm{K}_{2} \mathrm{HPO}_{4}, 1 \mathrm{mM} \mathrm{CaSO}, 1 \mathrm{mM} \mathrm{MgSO}_{4}, 10 \mathrm{mM}$ HEPES, $1 \mathrm{mg} / \mathrm{ml}$ glucose, $\mathrm{pH}$ 7.4). After washing, $1 \mathrm{ml}$ efflux buffer with $20 \mu \mathrm{Ci} / \mathrm{ml}$ of ${ }^{125} \mathrm{I}$ (Amersham) was added to each well and incubated for $1 \mathrm{~h}$ at $37^{\circ} \mathrm{C}$. After $1 \mathrm{~h}$, cells were rinsed seven times with $1 \mathrm{ml}$ of efflux buffer, and $1 \mathrm{ml}$ of efflux buffer with cAMP treatment cocktail $(500 \mu \mathrm{M}$ CPT-cAMP, $1 \mathrm{mM}$ isobutylmethylxanthine, $10 \mu \mathrm{M}$ forskolin) was added
}

into each well. After 5-min incubation, cells were lysed with $0.1 \mathrm{M} \mathrm{HNO}_{3}(1 \mathrm{ml})$ for $1.5 \mathrm{~h}$ at room temperature. All samples were counted with an autowell $\gamma$ counter (ARC-1000 M, Aloka). The percentage efflux of control or of cAMP-stimulated cells was calculated and expressed as: $\%$ efflux $=($ count secreted $) /($ total count remaining in the cells after $5 \mathrm{~min}) \times 100$.

\section{Real-Time Quantitative RT-PCR Analysis}

Total RNA from HaCaT cells was isolated using TRIZOL reagent (Invitrogen Life Technologies, UK) according to the recommended protocol. Synthesis of cDNA was performed using iScript ${ }^{\mathrm{TM}}$ cDNA Synthesis kit (Bio-Rad). Real-time quantitative RT-PCR analysis of NGF and GAPDH was performed using $\mathrm{iQ}^{\mathrm{TM}} \mathrm{SYBR}^{\circledR}$ Green Supermix (Bio-Rad). The NGF primers: (5'-CAGTTTTACCAAGGGAGCAGCTT- $3^{\prime}$ and $5^{\prime}$-CGCCTGTATGCCGATCAGA- $3^{\prime}$ ) and GAPDH primers: (5'-CGGGAAGCTTGTGATCAATGG-3' ${ }^{\prime}$ and $5^{\prime}$-GGCAGTGAT GGCATGGACTG- $3^{\prime}$ ) were used. The relative quantity of NGF mRNA was normalized using GAPDH as the internal control and expressed as the relative quantity of NGF mRNA (fold induction).

\section{Statistical Analysis}

Statistical analysis was performed by one-way ANOVA with either Tukey-Kramer multiple comparison test or Student's $t$-test (JMP software, SAS Institute, NC, USA) as indicated in each figure legend.

\section{RESULTS}

Increased Scratching Behavior and Skin Fibrotic Phenotypes in Skin of $\mathrm{Cftr}^{4 F 508 / 4 F 508}$ Mice Co-habiting with Mite-Positive Skin-Lesioned NC/Nga Mice

$\mathrm{Nc} / \mathrm{Nga}$ is an established mouse strain that facilitates the scratching behavior and the development of spontaneous skin lesions under rodent mite-positive condition. ${ }^{28}$ Rodent mite-free naive mice housed together with severely skinlesioned $\mathrm{Nc} / \mathrm{Nga}$ mice develop skin lesions. ${ }^{22}$ In this system, severity and persistence of symptoms seem to depend on the type of mouse strain and this phenotypic difference may be due to the difference of genetic background among the strain. $^{22,23}$ Thus, to examine a role of CFTR for the development of cutaneous symptoms, mice expressing dysfunctional F508del-Cftr $\left(C f t r^{\text {tmleur }} \text { Bl6; Cftr }{ }^{45508 / \Delta F 508}\right)^{20,21}$ were maintained in rodent mite-free environment or housed with mite-infested, skin-lesioned NC/Nga mice for 8 weeks, and scratching behavior was monitored. $\mathrm{Cftr}^{+/+}, \mathrm{Cftr}^{+/ \Delta F 508}$ and non-lesioned NC/Nga mice were also monitored as controls. The mice kept in mite-free environment had no skin aberrations (Figure 1a). However, the frequency of scratching significantly increased in Cftr ${ }^{4 F 508 / \Delta F 508}$ and NC/ Nga mice at the fifth week of co-housing with mite-bearing $\mathrm{NC/Nga} \mathrm{mice} \mathrm{(Figure} \mathrm{1b).} \mathrm{In} \mathrm{contrast,} \mathrm{the} \mathrm{scratching} \mathrm{beha-}$ vior of mite-infected $C \mathrm{ftr}^{+/+}, \mathrm{Cftr}{ }^{+/ \Delta F 508}$ mice was minimal during the experimental period (Figure 1b). At the eighth 


\section{a}

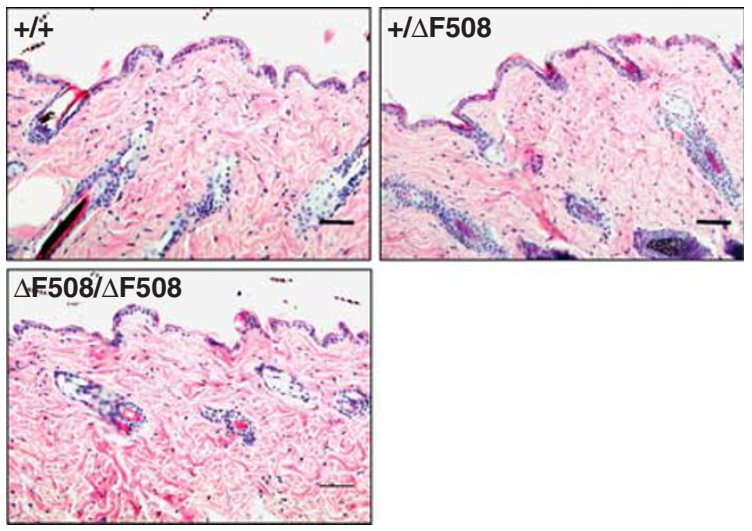

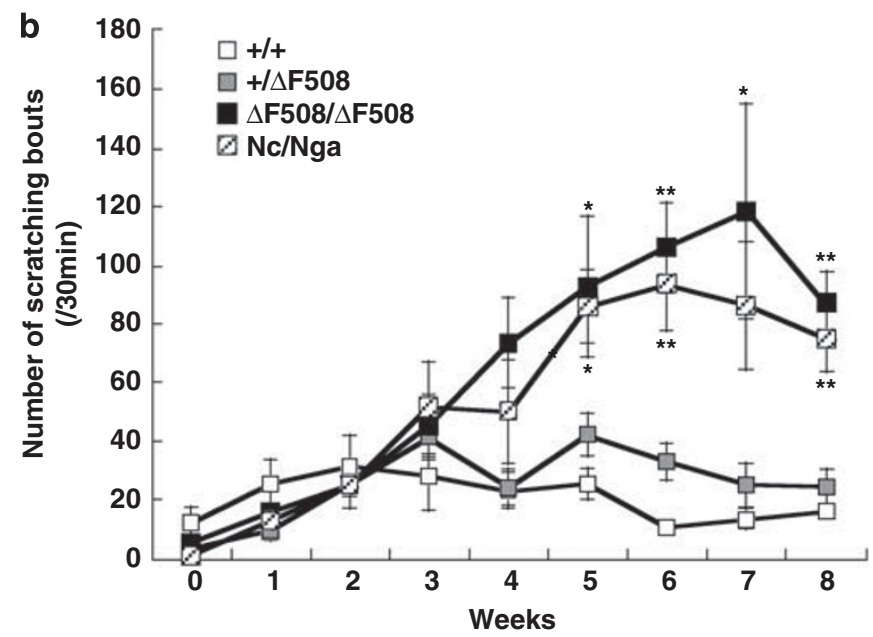

C

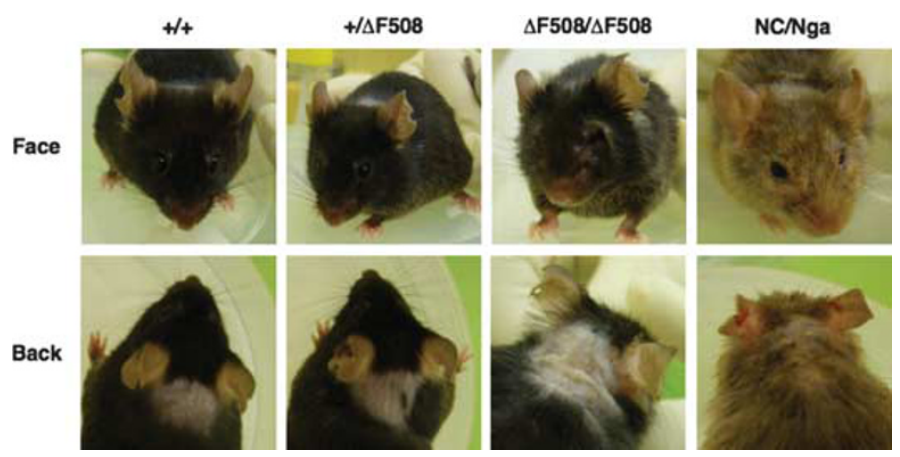

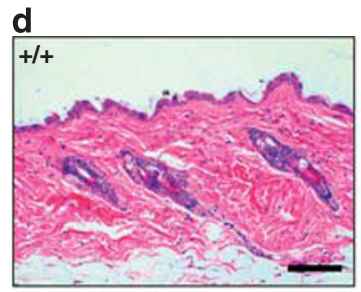

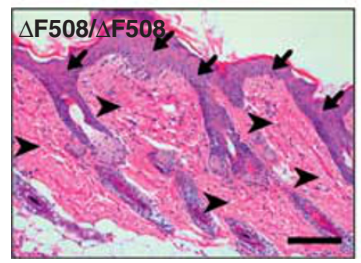

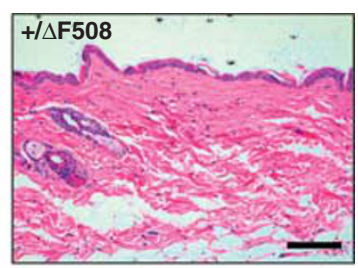

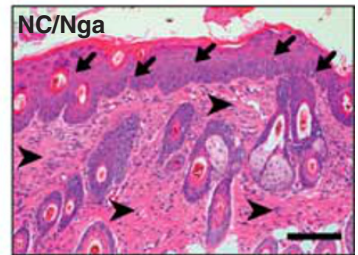

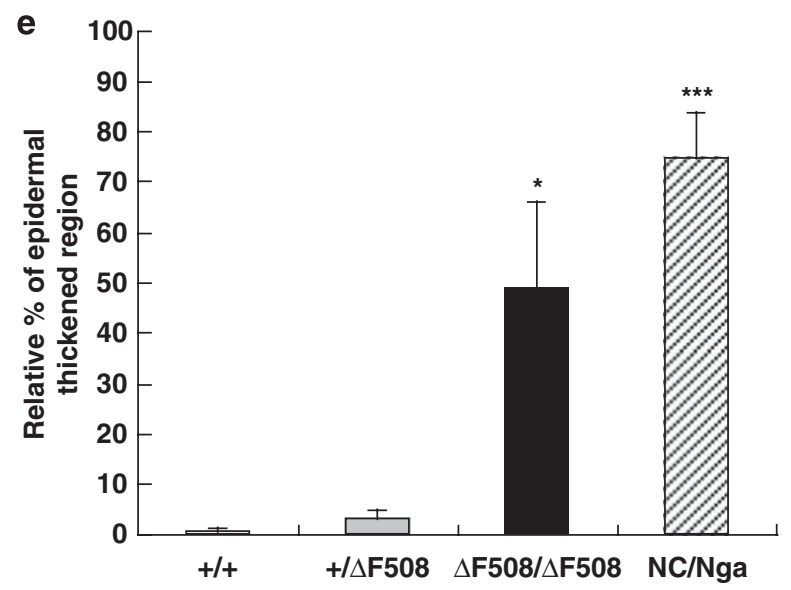

Figure 1 Increased scratching behavior and skin fibrosis in mite-infected $C f t r^{4 F 508 / 4 F 508}$ mice. (a) H\&E staining of rostral back skin sections in mite-free $\mathrm{Cftr}^{+/+}, \mathrm{Cftr}^{+/ 4 F 508}, \mathrm{Cftr}^{4 F 508 / 4 F 508}$ mice. Bars $=50 \mu \mathrm{m}$. (b-e) $\mathrm{Cftr}^{+/+}, \mathrm{Cftr}^{+/ 4 F 508}, \mathrm{Cftr}^{45508 / 4 F 508}$ ( $n=4$ per group) and non-lesioned NC/Nga mice $(n=5)$ were housed with mite-infested, skin-lesioned NC/Nga mice for 8 weeks. (b) Number of scratching episodes per 30 min was counted for each mouse. Data are presented as means \pm s.e.m. ${ }^{\star} P<0.05,{ }^{*} P<0.01 \mathrm{vs} \mathrm{Cftr}^{+/+}$mice, assessed by ANOVA with Tukey-Kramer procedure. (c) Gross appearance of mice at eighth week. Hair on the rostral back was shaved off using an electric razor before observation. (d) H\&E staining of rostral back skin sections of mice at eighth week. The arrow and arrowhead represent the epidermal-thickened region and dermal fibrosis, respectively. Bars $=50 \mu \mathrm{m}$. (e) Quantification of epidermal-thickened region of skin sections stained with H\&E expressed as the percent of epidermal-thickened region to total length of total skin sample. Data are presented as means \pm s.e.m. ( $n=4$ per group) ${ }^{\star} P<0.05,{ }^{* *} P<0.001$ vs wt $C \mathrm{ftr}^{+/+}$mice, assessed by one-way ANOVA with Tukey-Kramer procedure. 
week, the back skin of $C f t r^{4 F 508 / 4 F 508}$ mice appeared desiccated with accompanying signs of alopecia on the face (Figure 1c). Histological analysis of the skin of $C f t r^{4 F 508 / \Delta F 508}$ mice co-housed with mite-infested NC/Nga mice for 8 weeks showed significant increase in epidermal-thickened region and increase in dermal fibrosis while that of $C f t r{ }^{+/ 4 F 508}$ mice only had very slight increase in these skin fibrotic phenotypes (thickened epidermal tissue and dermal fibrosis) (Figure 1d and e). $\mathrm{Cftr}^{+/+}$mice skin did not exhibit skin fibrosis after co-housing with mite-infested $\mathrm{NC} / \mathrm{Nga}$ mice for 8 weeks (Figure 1d and e).

\section{Increased Neurite Density and NGF Level in Skin of Mite-Infested Cftr $^{\text {AF508/4F508 }}$ Mice}

Several studies suggest that epidermal neurite outgrowth is related to itching in the atopic skin, ${ }^{29,30}$ therefore, we examined whether neurite outgrowth in epidermis occurred in the skin of mite-infested $C f t r^{4 F 508 / \triangle F 508}$ mice at the eighth week of co-housing with skin-lesioned NC/Nga mice. We analyzed mice skin sections using PGP9.5 antibody, which stains sensory nerve endings. In mite-infested $\mathrm{Cftr}^{+/+}$, $C f r^{+/ \Delta F 508}$ mice, only a few PGP9.5-positive neurites were observed in the epidermal-dermal border (Figure $2 \mathrm{a},+I+$ and $+/ \Delta$ F508) after 8 weeks of exposure to mite. In contrast, PGP9.5-positive neurites were abundant in the epidermis of mite-infested $C f t r^{4 F 508 / \Delta F 508}$ mice and NC/Nga mice (Figure $2 \mathrm{a}, \Delta \mathrm{F} 508 / \Delta \mathrm{F} 508$ and $\mathrm{NC} / \mathrm{Nga}){ }^{29}$ The area of intraepidermal neurites was significantly increased in the epidermis of mite-infested $C f t r^{\triangle F 508 / \Delta F 508}$ mice compared with that of mite-infected CFTR ${ }^{+/+}$mice (Figure $2 \mathrm{~b}$ ).

It has been reported that NGF has effects on neurite outgrowth. ${ }^{31}$ Thus, we investigated the expression of NGF in the skin of mite-infested $C f t r^{4 F 508 / \Delta F 508}$ mice. In comparison with mite-infected $\mathrm{Cftr}^{+/+}$and $\mathrm{Cftr}^{+/ \Delta F 508}$ mice, a high expression of NGF (brown staining) was observed in the epidermis of $C f t r^{4 F 508 / 4 F 508}$ mice after 8 weeks of exposure to mite (Figure 3), consistent with the increased intra-epidermal neurites observed in these mice. Repeated application of K252a, a high-affinity NGF receptor inhibitor, to the rostral back of $C f t r^{4 F 508 / \triangle F 508}$ mice significantly inhibited the scratching behavior in mite-infested $\mathrm{Cftr}^{45508 / \Delta F 508}$ mice (Figure 4), suggesting a crucial role of NGF in the increased frequency of scratching in $C f t r^{45508 / \triangle F 508}$ mice exposed to mite. These results propose that CFTR dysfunction correlates with neurite outgrowth in/into epidermis accompanied with NGF hyperproduction in mice kept together with miteinfested $\mathrm{NC} / \mathrm{Nga}$ mice. Interestingly, although the skin TEWL, which represents an objective measure of skin barrier function, and the serum IgE level dramatically increased in $\mathrm{NC} / \mathrm{Nga}$ mice, which is expected in this mouse model of $\mathrm{AD},{ }^{28,32} \mathrm{TEWL}$ and serum IgE level did not significantly increase in mite-infected $C f t r^{\triangle F 508 / \triangle F 508}$ mice during an early period of mite infestation (Figure 5).

\section{Effect of Blocking the Chloride Channel on Scratching Behavior of $\mathrm{Cftr}^{+/+}$Mice}

We next hypothesized that the increased scratching behavior and dermatitis in Cftr ${ }^{4 F 508 / 4 F 508}$ mice was due to the dysfunction of chloride channel. To test this hypothesis, we orally administered GLB, an inhibitor of $\mathrm{Cl}^{-}$channel function, ${ }^{33}$ to wild-type C57BL/6J mice. GLB-treated mice housed with mite-infested, skin-lesioned NC/Nga mice had higher number of scratching episodes compared with their vehicle-treated counterparts (Figure 6). Scratching behavior

\section{a}
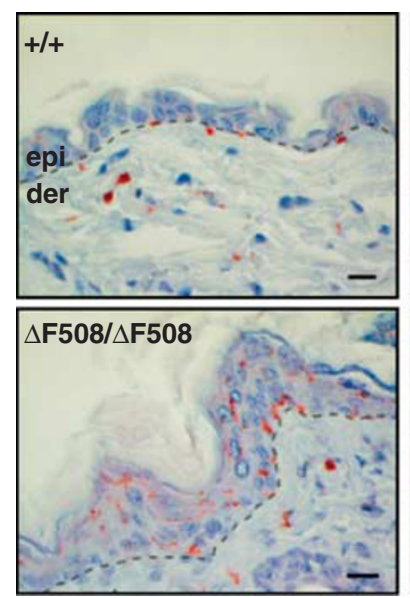

PGP9.5

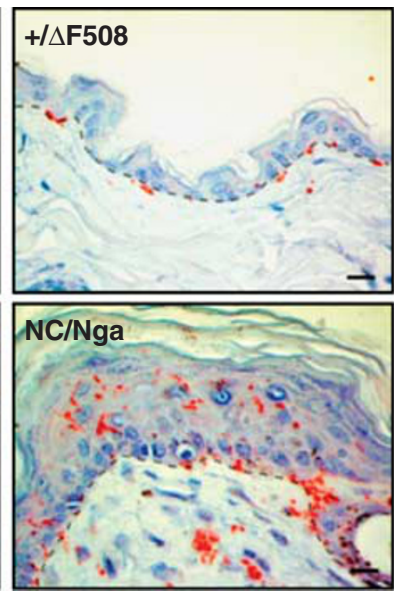

b

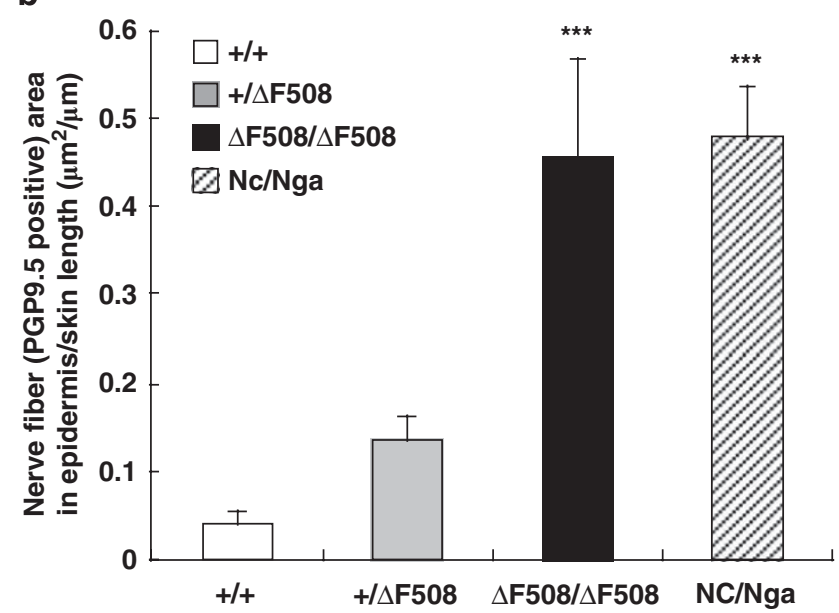

Figure 2 Increased neurite density in the skin of mite-infected $C \mathrm{ftr}^{4 F 508 / 4 F 508}$ mice. $\mathrm{Cftr}^{+/+}, \mathrm{Cftr}^{+/ \Delta F 508}, \mathrm{Cftr}^{4 F 508 / 4 F 508}$ ( $n=4$ per group) and non-lesioned NC/Nga mice $(n=5)$ were housed with mite-infested, skin-lesioned NC/Nga mice for 8 weeks. (a) Rostral back skin sections were stained with PGP9.5 (red staining). In all panels, the epidermal (epi)-dermal (der) border is shown by a broken line. Bars $=50 \mu$ m. (b) Quantification of PGP9.5-stained sections shown as the ratio of nerve fiber area in the epidermis to the length of skin sample, quantified using image software (WinROOF). Data are presented as means \pm s.e.m. $(n=4)$. ${ }^{* *} P<0.001$ vs wt CFTR mice, assessed by ANOVA with Dunnett procedure. 


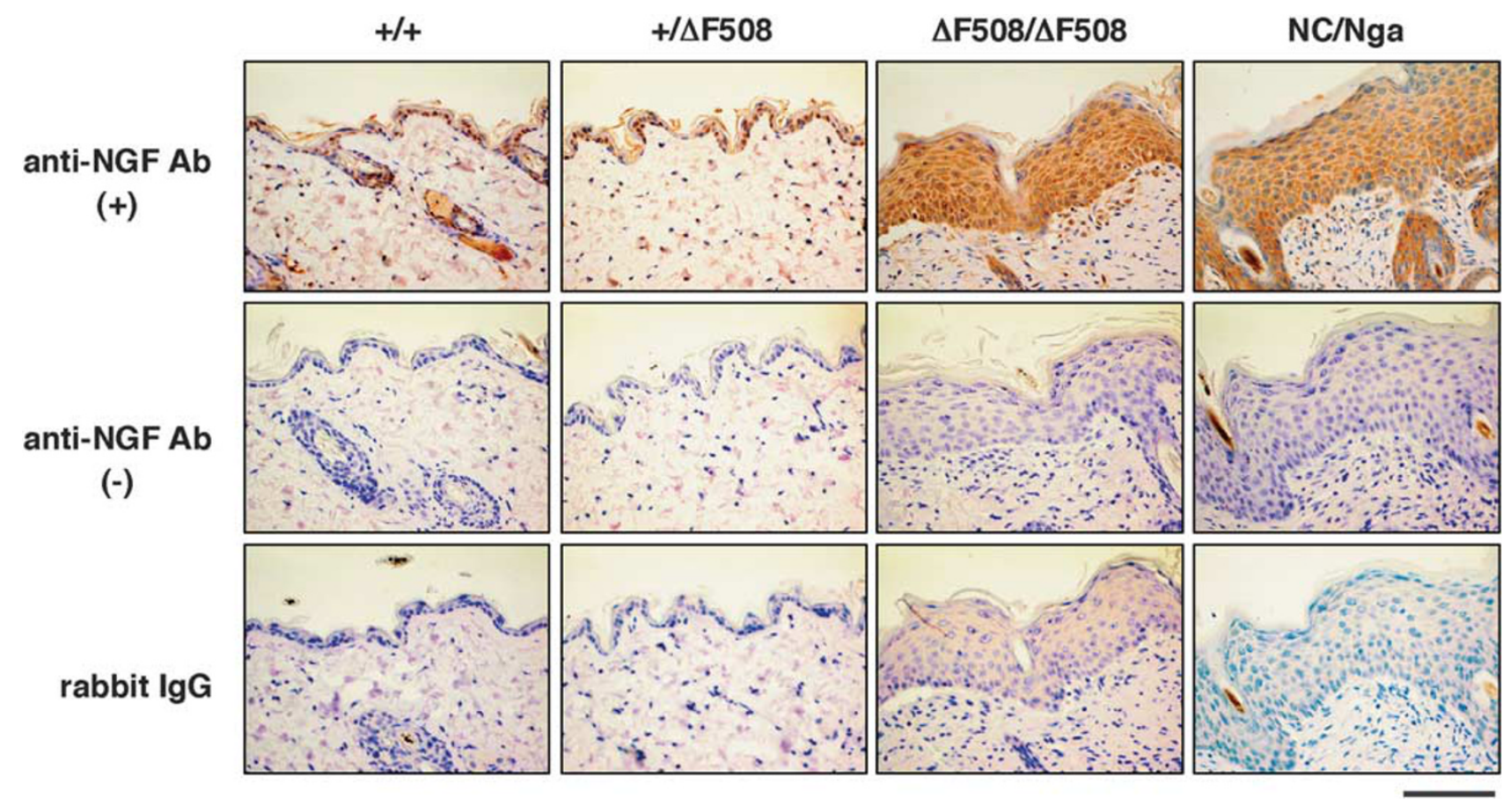

Figure 3 Increased NGF level in the skin of mite-infected $\mathrm{CFTR}^{4 F 508 / 4 F 508}$ mice. $\mathrm{Cftr}^{+/+}, \mathrm{Cftr}^{+/ 4 F 508}, \mathrm{Cftr}^{4 F 508 / 4 F 508}$ ( $n=4$ per group) and non-lesioned $\mathrm{NC} /$ Nga mice $(n=5)$ were housed with mite-infested, skin-lesioned NC/Nga mice for 8 weeks. Immunostaining of NGF in rostral back skin of mice was performed. As for negative controls, the same procedures were followed, but with isotype-matched Ig antibodies (rabbit lgG) and without the primary antibodies (anti-NGF Ab (-)). Bars $=100 \mu \mathrm{m}$.

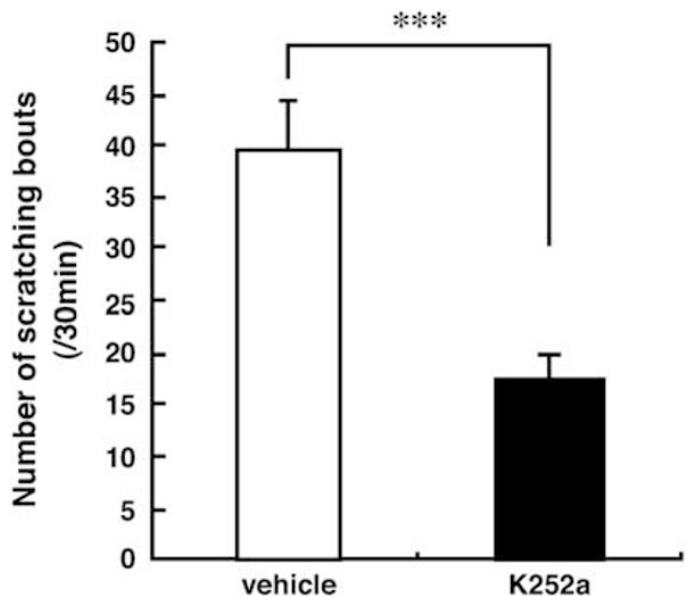

Figure 4 NGF is critical for the increased frequency of scratching in miteinfected $C f t r^{A F 508 / 4 F 508}$ mice. Vehicle or K252a was applied to the rostral part of CFTR ${ }^{4 F 508 / 4 F 508}$ mice 5 times a week for 3 weeks. The number of scratching movements directed at the rostral back was measured for $30 \mathrm{~min}$ at the third week of this study. Values are presented as means \pm s.e.m. ( $n=3-5$ mice). ${ }^{* *} P<0.005$ vs vehicle, assessed by Student's $t$-test.

did not change in GLB-treated C57BL/6J mice kept in mitefree environment (Figure 6a; GLB (SPF)). PGP9.5-positive nerve fibers and the area of intra-epidermal neurites were significantly increased in the epidermis of GLB-treated mice exposed to mite (Figure 6b). NGF expression was also higher in this group of mice compared to other groups (Figure 6c).

\section{Effect of Blocking the Chloride Channel on NGF Level in Keratinocytes}

Finally, we sought to determine whether these skin abnormalities observed in mite-infested $C f t r^{4 F 508 / \Delta F 508}$ mice are due to the CFTR dysfunction in keratinocytes, we utilized HaCaT cells, a keratinocyte cell line, to investigate the involvement of CFTR. We first confirmed the protein expression of CFTR by western blotting (Figure 7a) and immunofluorescence (Figure $7 \mathrm{~b}$ ) in $\mathrm{HaCaT}$ cells. ${ }^{125}$ I efllux analysis further revealed the functional expression of CFTR in HaCaT cells (Figure 7c). The inhibition of CFTR by specific inhibitor CFTR-inh $172^{34}$ did not affect the production of NGF mRNA (Figure 7d). Interestingly, in the presence of mite allergen, NGF mRNA level in cells significantly increased (Figure 7d). Consistently, the production of NGF mRNA in primary NHEK cells was also increased in the presence of mite allergen (Figure 7e). These data suggest that a dysfunction of CFTR $\mathrm{Cl}^{-}$channel correlates with hyperproduction of NGF in cells exposed to allergen and which, in vivo, may result in increased neurite outgrowth and increased scratching frequency in mite-infected mice.

\section{DISCUSSION}

In the present study, we assessed the effect of CFTR dysfunction on the development of cutaneous symptoms (itch, skin fibrosis) using dysfunctional Cftr $(\Delta \mathrm{F} 508$-Cftr)expressing $C f t r^{4 F 508 / 4 F 508}$ mice and CFTR inhibitors-treated 

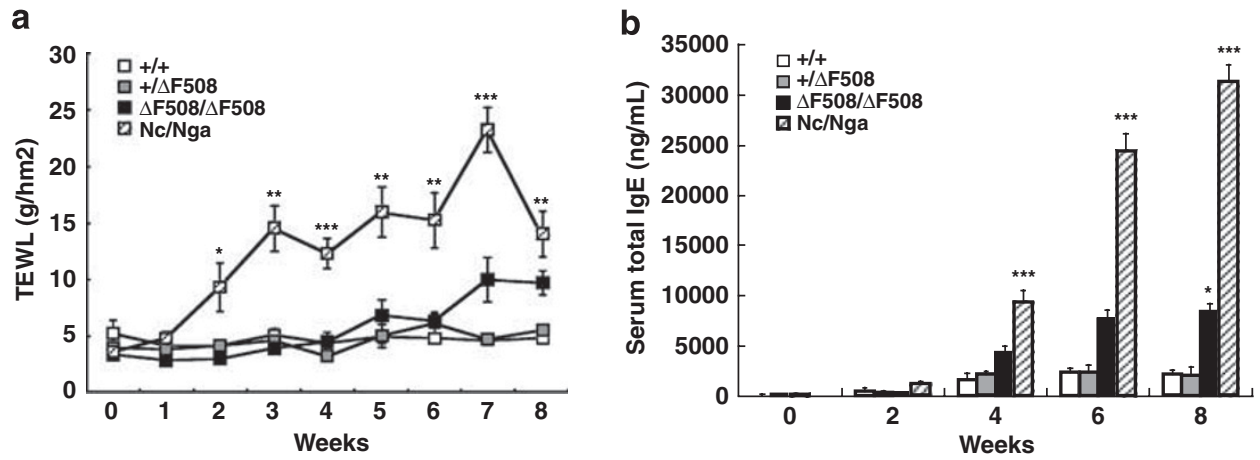

Figure 5 Skin TEWL and serum IgE level were not significantly increased in mite-infected $\mathrm{Cftr}^{4 F 508 / \Delta F 508}$ mice during an early period of mite infestation. (a) TEWL was measured quantitatively using the Tewameter on the shaved skin in the rostral back. Data are presented as means \pm s.e.m. ${ }^{\star} P<0.05$, ${ }^{* *} P<0.01,{ }^{* *} P<0.001$ vs $\mathrm{CFTR}^{+/+}$mice, assessed by ANOVA with Tukey-Kramer procedure. (b) Serum IgE concentrations were measured on weeks $0,2,4,6$ and 8. Data are presented as means \pm s.e.m. ${ }^{*} P<0.05$, ${ }^{* * * P}<0.001$ vs CFTR $^{+/+}$mice, assessed by one-way ANOVA with Tukey-Kramer procedure.

a

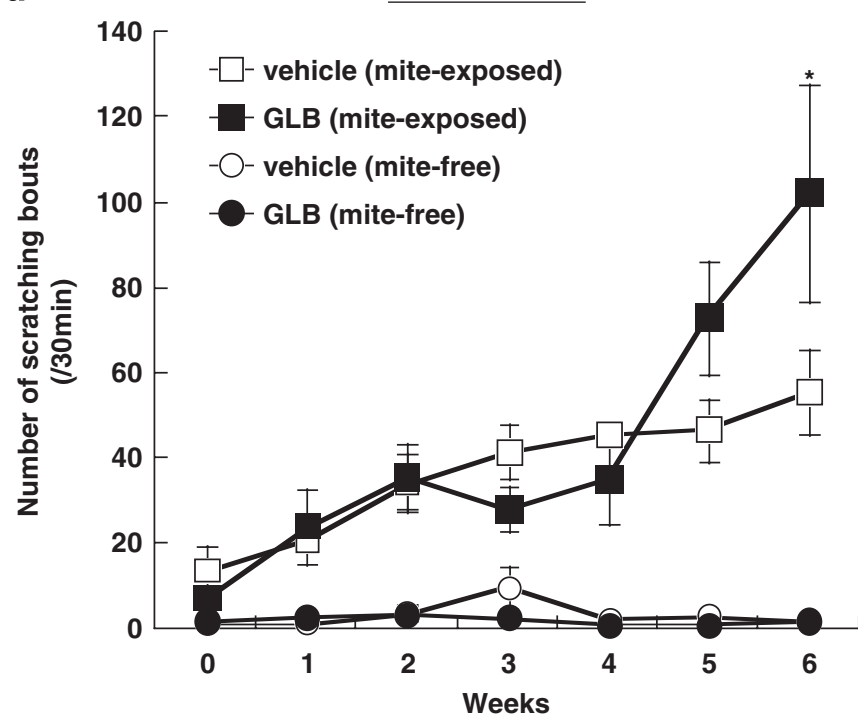

C

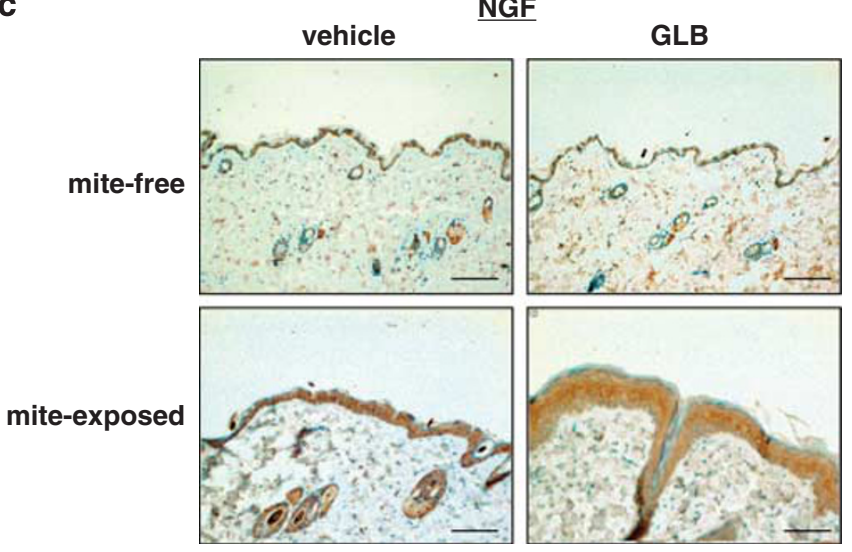

b
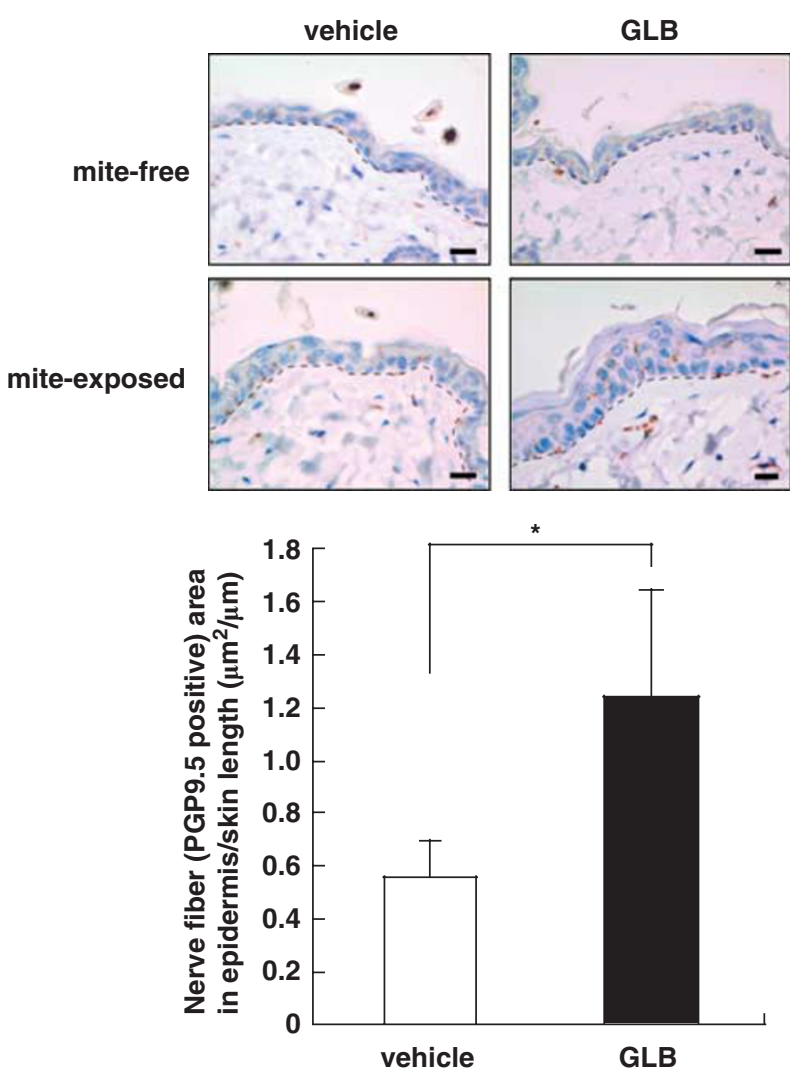

Figure 6 Influence of glibenclamide on the scratching behavior of C57BL/6J mice housed with skin-lesioned NC/Nga mice. C57BL/6J mice ( $n=4$ per group; CFTR wild type) housed with skin-lesioned NC/Nga mice or kept in mite-free environment were given, by oral administration, vehicle or glibenclamide ( $10 \mathrm{mg} / \mathrm{kg} /$ day) for 6 weeks. (a) Number of scratching episodes per $30 \mathrm{~min}$ was counted for each mouse. Data are presented as means \pm s.e.m. for four mice. ${ }^{\star} P<0.05$ vs vehicle (mite-exposed), assessed by Student's $t$-test. (b) Immunostaining of PGP9.5 (red staining) in rostral back skin of mice at the sixth week of this study. Bar $=50 \mu \mathrm{m}$. Quantification of PGP9.5-stained sections expressed as the ratio of nerve fiber area in the epidermis to the length of skin sample (lower panel). Values are the mean \pm s.e.m. $(n=4) .{ }^{*} P<0.05$ vs vehicle (mite-exposed), assessed by Student's $t$-test. (c) Immunostaining of NGF in back skin of mice at the sixth week of this study. Bars $=50 \mu \mathrm{m}$. 
a

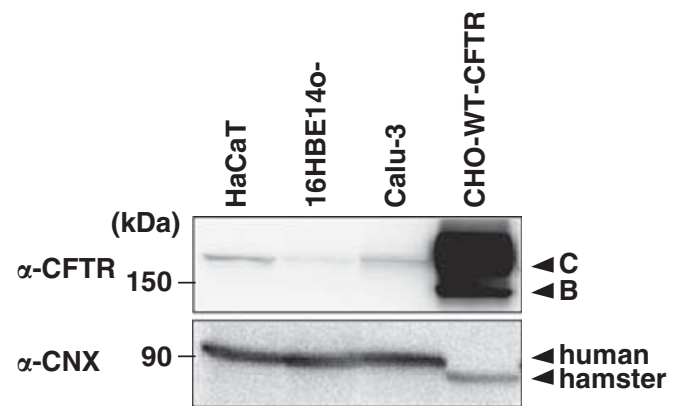

b

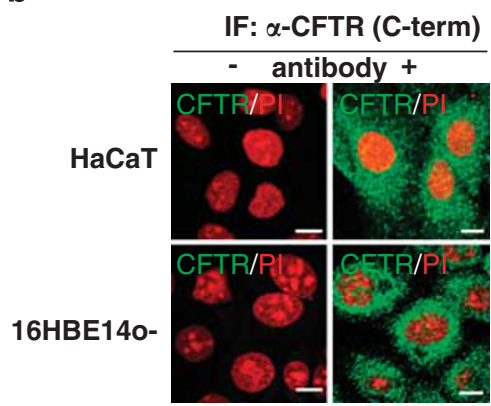

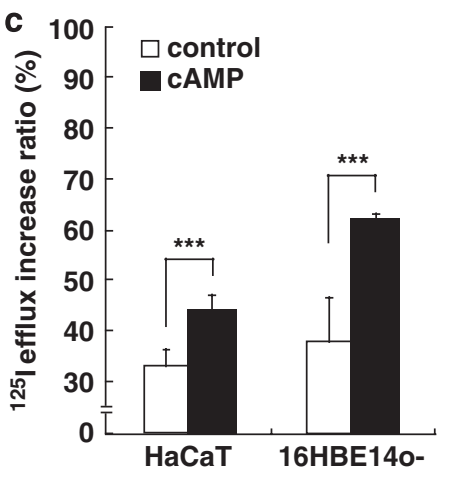
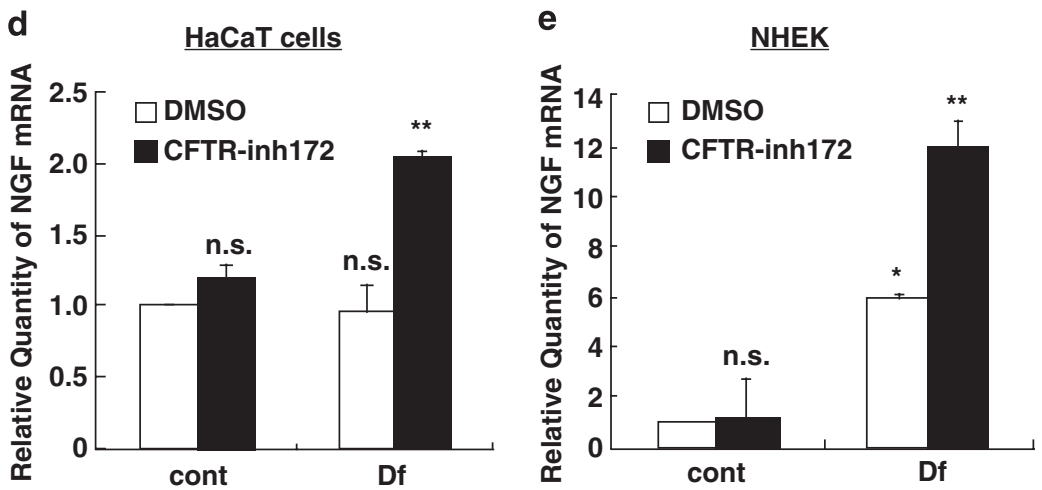

Figure 7 Inhibition of CFTR in human keratinocyte cell line HaCaT and primary normal human epidermal keratinocyte (NHEK) increased NGF mRNA. (a) Western blotting of CFTR (band B, immature CFTR; band C, mature CFTR) in HaCaT cells (lane 1), 16HBE14o- cells (lane 2), Calu-3 cells (lane 3) and WT-CFTR-expressing CHO cells (lane 4). In each well, $45 \mu \mathrm{g}$ of protein was loaded. Calnexin (CNX) expression was also determined to confirm the equal loading. Results are representative of three independent experiments. (b) Immunostaining of CFTR ( + ; green fluorescence) in HaCaT cells and 16HBE140- cells (positive control) using anti-CFTR antibody and nuclei labeled in red with propidium iodide (PI). Negative control (-) was without the primary antibody. Bars $=10 \mu \mathrm{m}$. (c) Confluent $\mathrm{HaCaT}$ cells were loaded with ${ }^{125} \mathrm{I}(20 \mu \mathrm{Ci} / \mathrm{ml})$ for $1 \mathrm{~h}$ then stimulated with cAMP cocktail for 5 min and ${ }^{125}$ I efflux was measured as described in Materials and methods. Data show means \pm s.e.m. $(n=6)$. ${ }^{* *} P<0.001$ against control, assessed with Student's $t$-test. (d, e) Real-time quantitative RT-PCR of NGF mRNA in HaCaT cells (d) and primary normal human epidermal keratinocytes (NHEK) (e) after stimulation with (Df) or without (cont) mite extract $(50 \mu \mathrm{g} / \mathrm{ml}$ for HaCaT; $100 \mu \mathrm{g} / \mathrm{ml}$ for NHEK) for $4 \mathrm{~h}$ in the presence of DMSO or CFTR-inh172 ( $10 \mu \mathrm{M}$ for HaCaT; $50 \mu \mathrm{M}$ for NHEK). NGF mRNA was normalized to the level of GAPDH (internal control). Data are presented as means \pm s.e.m. ${ }^{*} P<0.05,{ }^{*} P<0.005$ vs cont DMSO, assessed by ANOVA with Tukey-Kramer procedure. n.s., not significant.

mice and keratinocytes. Despite no detectable cutaneous symptoms under rodent mite (M. musculi)-free condition, the $C f t r^{4 F 508 / 4 F 508}$ mice, but not $\mathrm{Cftr}^{+/+}$and $\mathrm{Cftr}^{+/ 4 F 508}$ mice, displayed an increased number of scratching count and skin fibrosis during mite infestation. This is likely due to the increased levels of NGF and PGP9.5 in mite-infested $C f t r^{\triangle F 508 / \triangle F 508}$ mice because treatment of $C f t r^{4 F 508 / \triangle F 508}$ mice with K252a, a high-affinity NGF receptor inhibitor that is also shown to dampen PGP9.5 expression via NGF suppression, ${ }^{8}$ significantly inhibited the scratching behavior in mite-infested Cftr ${ }^{4 F 508 / 4 F 508}$ mice. Although we cannot exclude the possibility of occurrence of increased levels of NGF and PGP9.5 in mite-free Cftr ${ }^{4 F 508 / \Delta F 508}$ mice, our results propose that CFTR dysfunction may correlate with neurite outgrowth in/into epidermis accompanied with NGF hyperproduction in mice kept together with mite-infested $\mathrm{NC/Nga}$ mice. This idea was further supported by the experiment using CFTR inhibitors. In in vivo experiment, although we could not exclude the possible involvement of non-specificity of GLB because GLB affects not only CFTR
$\mathrm{Cl}^{-}$channel function but also various channels through the inhibition of ATP-sensitive potassium channels, the fact that cutaneous phenotypes between our dysfunctional Cftr $\left(\Delta \mathrm{F} 508\right.$-Cftr)-expressing $C f t r^{\triangle F 508 / 4 F 508}$ mice and GLBtreated mice are quite similar may lead us to suggest the specific involvement of CFTR $\mathrm{Cl}^{-}$channel function in the regulation of NGF expression and itch sensation.

Our data also suggest that CFTR dysfunction does not trigger spontaneous dermatosis but may affect the susceptibility to skin allergen such as mite extract. This is quite similar to that observed in NC/Nga mice ${ }^{28}$ and DS non-hair (DS-Nh) mice. ${ }^{35}$ These mice have also been shown to be quite sensitive to external stimuli including mite infestation or Staphylococcus aureus infection, which triggers the clinical AD-like symptoms such as itching, erythema, hemorrhage, scaling, dryness and alopecia at the age of 8 weeks, although molecular mechanisms responsible for this increased sensitivity is not clearly understood. As we showed that CFTR dysfunction causes increased susceptibility to mite-induced dermatitis, associated with NGF up-regulation and induction 
of itch-induced scratching behavior, CFTR might play a role, at least in part, in the development of cutaneous symptoms in these mice. The precise analysis of $\mathrm{Cftr}$ expression and sequence in $\mathrm{NC} / \mathrm{Nga}$ mice would allow us to determine if mite-induced induction of itch sensation and scratching behavior depends on Cftr in NC/Nga mice.

It is still unclear how NGF expression is dysregulated in mite-exposed $C f t r^{4 F 508 / \triangle F 508}$ mice. Whether it is up-regulation of molecules required for the recognition of mite or increased susceptibility to the mite attachment to the skin requires further study. In order to explore the former possibility, we sought to identify the key molecules responsible for the recognition of mite invasion. Interestingly, our preliminary data showed an increased responsiveness of TLR2, one of the receptors that we recently identified as an important molecule for the increased responsiveness of human $C F T R^{4 F 508 / \triangle F 508}$ bronchial epithelial cells towards bacterial peptidoglycan, ${ }^{17,36}$ in CFTR-inhibitor-treated HaCaT cells, but not in non-treated cells (Supplementary Figure 1). This implies that CFTR function in human or mice skin tissues may be important for the control of TLR2-dependent signaling. Whether dysregulated TLR2 signaling is involved in the increased expression of NGF in mite-exposed and CFTRinhibitor-treated $\mathrm{HaCaT}$ cells is currently under investigation. For the latter possibility, we need to clarify the barrier function of skin in our system. As we mentioned, a skin TEWL, which is a marker of skin barrier function, was examined in mite-exposed mice. TEWL rate in $C f t r^{4 F 508 / \Delta F 508}$ mice was not affected during the first 6 weeks of exposure although it tended to increase at 6 and 8 weeks of exposure, whereas in $\mathrm{Nc} / \mathrm{Nga}$ mice TEWL increased significantly (Figure 5a). As both strains showed a strong skin response when exposed to mite (Figures 2-4), this suggests that CFTR may also affect the skin barrier function during a late period of mite infestation. Notably, mice that lack $\mathrm{ENaC}^{37}$ and $\mathrm{AQP} 3,{ }^{38}$ both of which are thought to be positively regulated by CFTR in the skin tissue, are required for the postnatal maintenance of the epidermal barrier function, suggesting that CFTR defect may decrease the barrier function of skin via dysregulation of ENaC and AQP3. ${ }^{13,14}$

Despite the importance of NGF for the phenotypes such as neurite outgrowth and increased itch sensation in miteexposed $C f t r^{4 F 508 / \triangle F 508}$ mice, the possibility that the mechanism may involve the depolarizing calcium activated chloride currents in the primary afferent fibers in $C f t r^{\Delta F 508 / \triangle F 508}$ mice cannot be excluded. In fact, reduced extracellular epidermal chloride concentration has been shown to sensitize epidermal endings, which is considered to promote depolarizing calcium activated chloride currents in the primary afferent fibers, by increasing the equilibrium potential for chloride. Further studies are needed to determine whether the extracellular chloride concentrations contributes the development of itch sensation in $C f t r^{4 F 508 / \Delta F 508}$ mice.

Overall, our study demonstrates that Cftr dysfunction in mice leads to abundant neurite outgrowth in epidermis,

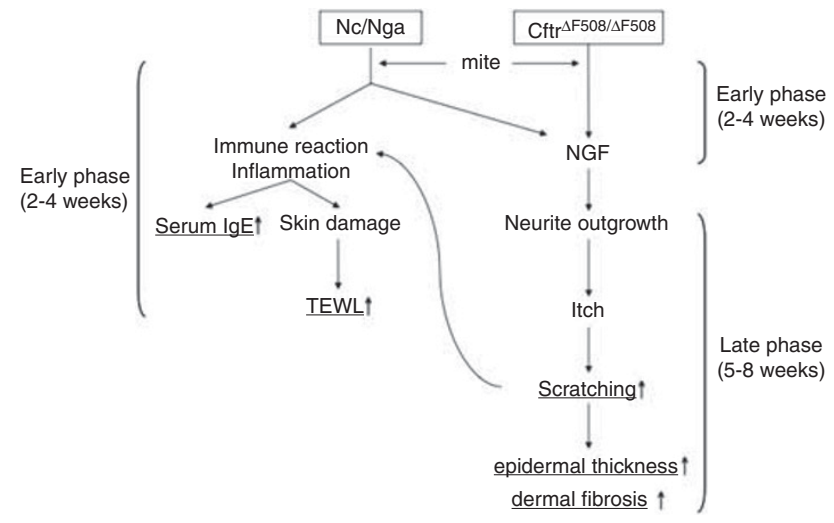

Figure 8 Hypothetical model of mite-induced cutaneous symptoms in $\mathrm{Nc} / \mathrm{Nga}$ mice and $\mathrm{Cftr}{ }^{45508 / 4 F 508}$ mice. Normally, in the mouse model for atopic dermatitis such as $\mathrm{Nc} / \mathrm{Nga}$ mice, in addition to increased scratching behavior, increased rates of TEWL and increased serum IgE levels can be also observed during the first 6 weeks of mite exposure (early phase) because of spontaneous immune reaction and inflammation. On the other hand, as shown in our study, the rates of TEWL and serum lgE levels in $\mathrm{Cftr}^{4 F 508 / 4 F 508}$ mice have been less affected during the first 6 weeks although these tended to increase at 7 and 8 weeks of exposure. Based on these results, CFTR dysfunction in mite-exposed mice might dominantly induce the scratching behavior possibly via the production of NGF and neurite growth, followed by the itch/scratching-induced immune reaction and inflammation that increase the rates of TEWL and the level of IgE during the late stage of mite exposure in $\mathrm{Cftr}^{4 F 508 / \Delta F 508}$ mice.

accompanied with NGF hyperproduction, followed by itch-scratch cycle that develops to cutaneous fibrosis in the presence of mite. As increased expression of NGF has been shown to contribute to the development of $\mathrm{AD}$-like symptoms in mice models of $\mathrm{AD}$ such as $\mathrm{Nc} / \mathrm{Nga}^{7,8}$ and DS-Nh mice, ${ }^{35} C f t r^{4 F 508 / 4 F 508}$ mice may also serve as a useful model for understanding of pruritus symptom in some cutaneous diseases such as AD. However, increased rates of TEWL and serum IgE level, the typical phenotypes of AD mice model $\mathrm{Nc} / \mathrm{Nga}$ because of spontaneous immune reaction and inflammation, ${ }^{7,8}$ were not observed during the first 6 weeks of mite exposure in $C f t r^{4 F 508 / 4 F 508}$ mice although these tended to increase at 7 and 8 weeks of exposure. These data led us to hypothesize that CFTR dysfunction in mite-exposed mice might dominantly induce the scratching behavior possibly via the production of NGF and neurite growth, but not skin damage itself, followed by the increase in rates of TEWL and levels of serum IgE after skin damage induced by the scratching occurs at the late stage of mite exposure in $C f t r^{4 F 508 / \Delta F 508}$ mice (itch-scratching-skin damage cycle) (Figure 8). In this aspect, molecular mechanisms of how cutaneous symptoms develop seem to be different between $\mathrm{Nc} / \mathrm{Nga}$ and $C f t r^{\triangle F 508 / \triangle F 508}$ mice.

Supplementary Information accompanies the paper on the Laboratory Investigation website (http://www.laboratoryinvestigation.org)

\section{ACKNOWLEDGEMENT}

We acknowledge the technical assistance of Norikazu Takano, Jun-ichi Yoshida, Yuko Ohira, Eriko Watanabe, Kenji Watanabe, Yuichiro Shimauchi, 
Shingo Suzuki and Tomomi Ono. This work was supported in part by grants from the Ministry of Education, Science, Sport and Culture (MEXT) of Japan, the Nakatomi Foundation and the Global COE Program (Cell Fate Regulation Research and Education Unit), MEXT, Japan. Dr Martina Wilke, Erasmus MC biochemistry provided the C57BI/6 backcrossed $\mathrm{Cftr}^{\text {tmleur }}$ breeding stock, the ERASMUS MC CF mouse colony was sponsored by EUROCARECF (LSHM-CT-2005-018932).

\section{DISCLOSURE/CONFLICT OF INTEREST}

The authors declare no conflict of interest.

1. Kimura T, Miyazawa $H$. The 'butterfly' sign in patients with atopic dermatitis: evidence for the role of scratching in the development of skin manifestations. J Am Acad Dermatol 1989;21:579-580.

2. Wahlgren CF. Itch and atopic dermatitis: an overview. J Dermatol 1999:26:770-779.

3. Koblenzer CS. Itching and the atopic skin. J Allergy Clin Immunol 1999;104:S109-S113.

4. Ikoma A, Steinhoff $M$, Stander $S$, et al. The neurobiology of itch. Nat Rev Neurosci 2006;7:535-547.

5. Ishiuji Y, Coghill RC, Patel TS, et al. Repetitive scratching and noxious heat do not inhibit histamine-induced itch in atopic dermatitis. $\mathrm{Br}$ Dermatol 2008;158:78-83.

6. Paus $R$, Schmelz $M$, Biro $T$, et al. Frontiers in pruritus research: scratching the brain for more effective itch therapy. J Clin Invest 2006;116:1174-1186.

7. Takano N, Sakurai T, Kurachi M. Effects of anti-nerve growth factor antibody on symptoms in the NC/Nga mouse, an atopic dermatitis model. J Pharmacol Sci 2005;99:277-286.

8. Takano N, Sakurai T, Ohashi $Y$, et al. Effects of high-affinity nerve growth factor receptor inhibitors on symptoms in the NC/Nga mouse atopic dermatitis model. Br J Dermatol 2007;156:241-246.

9. Toyoda M, Nakamura M, Makino T, et al. Nerve growth factor and substance $\mathrm{P}$ are useful plasma markers of disease activity in atopic dermatitis. Br J Dermatol 2002;147:71-79.

10. Ratjen F, Doring G. Cystic fibrosis. Lancet 2003;361:681-689.

11. Cheng SH, Gregory RJ, Marshall J, et al. Defective intracellular transport and processing of CFTR is the molecular basis of most cystic fibrosis. Cell 1990;63:827-834.

12. Anderson MP, Berger HA, Rich DP, et al. Nucleoside triphosphates are required to open the CFTR chloride channel. Cell 1991;67:775-784.

13. Berdiev BK, Cormet-Boyaka E, Tousson A, et al. Molecular proximity of cystic fibrosis transmembrane conductance regulator and epithelial sodium channel assessed by fluorescence resonance energy transfer. J Biol Chem 2007;282:36481-36488.

14. Schreiber R, Nitschke R, Greger R, et al. The cystic fibrosis transmembrane conductance regulator activates aquaporin 3 in airway epithelial cells. J Biol Chem 1999;274:11811-11816.

15. Osika E, Cavaillon JM, Chadelat K, et al. Distinct sputum cytokine profiles in cystic fibrosis and other chronic inflammatory airway disease. Eur Respir J 1999;14:339-346.

16. Aujla SJ, Chan YR, Zheng M, et al. IL-22 mediates mucosal host defense against Gram-negative bacterial pneumonia. Nat Med 2008;14:275-281.

17. Shuto T, Furuta T, Oba M, et al. Promoter hypomethylation of Toll-like receptor-2 gene is associated with increased proinflammatory response toward bacterial peptidoglycan in cystic fibrosis bronchial epithelial cells. FASEB J 2006:20:782-784.

18. Jacquot J, Tabary $\mathrm{O}$, Clement $\mathrm{A}$. Hyperinflammation in airways of cystic fibrosis patients: what's new? Expert Rev Mol Diagn 2008:8:359-363.
19. Sato $F$, Soos $G$, Link $C$, et al. Cystic fibrosis transport regulator and its mRNA are expressed in human epidermis. J Invest Dermatol 2002:119:1224-1230.

20. van Doorninck JH, French PJ, Verbeek E, et al. A mouse model for the cystic fibrosis delta F508 mutation. EMBO J 1995;14:4403-4411.

21. French PJ, van Doorninck JH, Peters RH, et al. A delta F508 mutation in mouse cystic fibrosis transmembrane conductance regulator results in a temperature-sensitive processing defect in vivo. J Clin Invest 1996;98:1304-1312.

22. Takano N, Arai I, Kurachi M. A method to induce stable atopic dermatitis-like symptoms in NC/Nga mice housed with skin-lesioned mice. Br J Dermatol 2006:154:426-430.

23. Hashimoto Y, Arai I, Takano N, et al. Induction of scratching behaviour and dermatitis in various strains of mice cohabiting with $\mathrm{NC} / \mathrm{Nga}$ mice with chronic dermatitis. Br J Dermatol 2006;154:28-33.

24. Koizumi S, Contreras ML, Matsuda Y, et al. K-252a: a specific inhibitor of the action of nerve growth factor on PC 12 cells. J Neurosci 1988:8:715-721.

25. Boukamp P, Petrussevska RT, Breitkreutz D, et al. Normal keratinization in a spontaneously immortalized aneuploid human keratinocyte cell line. J Cell Biol 1988;106:761-771.

26. Hashimoto $\mathrm{Y}$, Okiyoneda $\mathrm{T}$, Harada $\mathrm{K}$, et al. Phosphatidic acid metabolism regulates the intracellular trafficking and retrotranslocation of CFTR. Biochim Biophys Acta 2008;1783:153-162.

27. Harada K, Okiyoneda T, Hashimoto Y, et al. Curcumin enhances cystic fibrosis transmembrane regulator expression by down-regulating calreticulin. Biochem Biophys Res Commun 2007;353:351-356.

28. Suto $H$, Matsuda $H$, Mitsuishi $K$, et al. NC/Nga mice: a mouse model for atopic dermatitis. Int Arch Allergy Immunol 1999;120(Suppl 1): 70-75.

29. Horiuchi Y, Bae S, Katayama I. Nerve growth factor (NGF) and epidermal nerve fibers in atopic dermatitis model $\mathrm{NC} / \mathrm{Nga}$ mice. J Dermatol Sci 2005;39:56-58.

30. Tominaga $\mathrm{M}$, Ozawa $\mathrm{S}$, Ogawa $\mathrm{H}$, et al. A hypothetical mechanism of intraepidermal neurite formation in $\mathrm{NC} / \mathrm{Nga}$ mice with atopic dermatitis. J Dermatol Sci 2007;46:199-210.

31. Bennett $\mathrm{DL}$, Koltzenburg $\mathrm{M}$, Priestley JV, et al. Endogenous nerve growth factor regulates the sensitivity of nociceptors in the adult rat. Eur J Neurosci 1998;10:1282-1291.

32. Matsuda H, Watanabe N, Geba GP, et al. Development of atopic dermatitis-like skin lesion with IgE hyperproduction in NC/Nga mice. Int Immunol 1997;9:461-466.

33. Sheppard DN, Welsh MJ. Effect of ATP-sensitive K+ channel regulators on cystic fibrosis transmembrane conductance regulator chloride currents. J Gen Physiol 1992;100:573-591.

34. Ma $\mathrm{T}$, Thiagarajah JR, Yang $\mathrm{H}$, et al. Thiazolidinone CFTR inhibito identified by high-throughput screening blocks cholera toxin-induced intestinal fluid secretion. J Clin Invest 2002;110:1651-1658.

35. Yoshioka T, Hikita I, Asakawa $M$, et al. Spontaneous scratching behaviour in DS-Nh mice as a possible model for pruritus in atopic dermatitis. Immunology 2006;118:293-301.

36. Furuta $T$, Shuto T, Shimasaki $\mathrm{S}$, et al. DNA demethylation-dependent enhancement of toll-like receptor-2 gene expression in cystic fibrosis epithelial cells involves SP1-activated transcription. BMC Mol Biol 2008;9:39.

37. Charles RP, Guitard M, Leyvraz C, et al. Postnatal requirement of the epithelial sodium channel for maintenance of epidermal barrier function. J Biol Chem 2008;283:2622-2630.

38. Ma $\mathrm{T}$, Hara $\mathrm{M}$, Sougrat $\mathrm{R}$, et al. Impaired stratum corneum hydration in mice lacking epidermal water channel aquaporin-3. J Biol Chem 2002;277:17147-17153. 